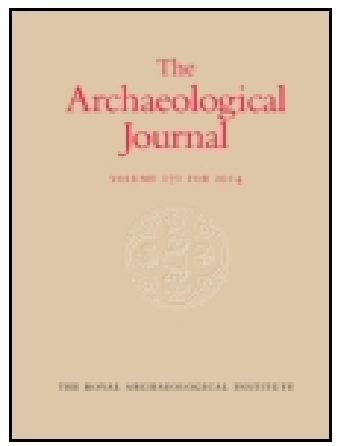

Archaeological Journal

\title{
On the Discovery of the Remains of John, First Earl of Shrewsbury, at Whitchurch
}

\section{Stephen Tucker Rouge Croix}

To cite this article: Stephen Tucker Rouge Croix (1877) On the Discovery of the Remains of John, First Earl of Shrewsbury, at Whitchurch, Archaeological Journal, 34:1, 386-394, DOI: 10.1080/00665983.1877.10851787

To link to this article: http://dx.doi.org/10.1080/00665983.1877.10851787

曲 Published online: 14 Jul 2014.

Submit your article to this journal $₫$

Q View related articles $₫$ 
ON THE DISCOVERY OF THE REMAINS OF JOHN, FIRST FART, OF SHREWSBURY, AT WHITCHURCH.

BY STEPHEN TUCKER, ROUGE CROIX.

Although full accounts, which I will presently enumerate, appeared at the time as to the discovery of the great Talbot's bones beneath his well-known effigy at Whitchurch, I hope the subject may be deemed of sufficient interest, from the intimate connection of the Earl and his family with this immediate neighbourhood, to justify me in again bringing it forward, and particularly as there are one or two points not hitherto referred to, which appear to me to add importance to the curions evidences of identity of the remains already collected.

Any lengthened details of the history and exploits of the great soldier, John Talbot, will not be expected from me, for, devoting as he did, the best part of his eighty years to the service of his country in the warlike periods of Henry the Fourth, Fifth, and Sixth, and embracing the whole career of Joan of Arc of France, his chivalrous deeds have been again and again recounted, and rendered specially immortal by Shakespeare himself.

He was the second son of Richard Talbot, of Goodrich Castle, in this county, to whom, by the death of the elder brother, he became heir, and marrying the heiress of Lord Furnival had summons to Parliament in that dignity. He subsequently earned and received many other honours and the Earldom of Shrewsbury, and after a life of brilliant military achievements, died on the field of Chatillon, 20th July, 1453.

On the 9th of March, 1874, some workmen removed the effigy of the Earl, at Whitchurch, in preparation $f \circ$. some contemplated repairs of the canopy and front of the monument, and found underneath a sort of case or coffin, containing (with the exception of some vertebrie) an entire skeleton, each bone of which was separately and carefully encased in cere cloth. The rector (the Rev. W. H. Egerton) at once communicated with the repre- 
sentative (the recently deceased Earl of Shrewsbury), with Earl Brownlow, the present owner of the Blakemere property, and others, and forwarded an account of the discovery to the Society of Antiquaries, which was there read on 12 th March, Mr. Knight Watson giving a resumé, from contemporaneous chroniclers, of the manner of the Earl's death. Later in the month, Mr. Earwaker, of Merton College, Oxford, communicated Ashmole's own notes (from his MS., No. 854, Bodleian), taken at Whitchurch, 31 August, 1663. He describes the tomb, says there was then no epitaph remaining, but quotes, from a MS. of 1598, of some extracts from the Whitchurch Register, a full roll of his titles, which had formed an inscription; and gives also the Latin wording of a brass which formerly existed in the church, recording his name and titles and his death, "in bello apud Burdowe," as on the 17th July, 1453. I may here say that a lengthened notice of the discovery of the bones and the Earl's history appeared in the Shrewsbury Journal of 18th March, and more full ones still, with an account of the ceremony and service on the re-interment of the remains, in the Whitchurch Parish Magazine, in the monthly numbers for April and May, 1874.

Mr. Egerton corresponded with me, and I took some pains to ascertain where the Earl was really buried, and to assist in identifying the remains from the various circumstances recorded of his death. I found conflicting statements as to the place of his burial. Most modern writers, and several early ones of repute, were agreed that he was interred at Whitchurch; but he was otherwise said to have been buried at Rouen and at Blakemere. There were grounds, as I will show, for both these statements. Ralph Brooke, in his Catalogue of Nobility, gave Rouen as the place; and Augustine Vincent (Windsor Herald), in his Discoveries of Errours in Brooke, ever ready, and, I may add, able to correct him, points out the mistake. I referred to the Earl's will, which was dated at Portsmouth, 1 Sept., 1452, and was proved at Lambeth 18th January, 1453-4, and there I found the direction "My body to be beryed at Blakemere in the paryshe church on the right side of the chancell." I wrote to the rector (the Rev. Andrew Pope), and heard 
that there was not even a tradition of this direction having been acted upon, for although contained in one of the last instruments he could have executed, it was overruled by a promise he is reported to have made to his body-guard of Whitchurch men, who, rallying round him when in imminent danger in one of his battles, said to be that of Patay, saved his life, that he would be laid in Whitchurch. That he was first interred at Rouen there can be no doubt, and hence that place has been recorded as that of his burial, but his remains were brought from thence forty years after his death by his grandson, Sir Gilbert Talbot, of Grafton, who led the right wing of Richmond's army at Bosworth, and buried where they were found - the heart embalmed, in a silver urn covered with crimson velvet, had been buried in the porch, probably immediately after his death. Sir Gilbert was the founder of the chauntry at Whitchurch, and died 9th year of Henry VIII.

I now come to the means of identifying the bones. The Earl was not only wounded at Chatillon, but his horse being killed, he lay on the ground, and in this position was "despatched," as it has been said, by a blow on the head, probably from an axe. Shakespeare's account of Sir William Lucy coming to the French prince, when seeking for Talbot's body, will be remembered:-

Sir W. Lucy: Herald, conduct me to the Dauphin's tent,

To know who hath obtained the glory of the day.

Charles: On what submissive message art thou sent?

Sir W. Lucy: Submission, Dauphin! 'tis a mere French word;

We English warriors wot not what it means.

I come to know what prisoners thou hast ta'en,

And to survey the bodies of the dead.

Charles: For prisoners ask'st thou? Hell our prison is.

But tell me whom thou seek'st?

Sir W. Lucy: But where's the great Alcides of the field,

Valiant Lord Talbot, Earl of Shrewsbury,

Created, for his rare success in arms,

Great Earl of Washford, Waterford, and Valence ;

Lord Talbot of Goodrig and Urchinfield,

Lord Strange of Blackmere, Lord Verdun of Alton,

Lord Cromwell of Wingfield, Lord Furnival of Sheffield,

The thrice victorious Lord of Falconbridge;

Knight of the noble order of Saint George,

Worthy Saint Michael and the Golden Fleece;

Great Marshal to Heury the Sixth

Of all his wars within the realm of France? 





Shakespeare was right in this. The body was anxiously sought for by many, and was at last identified by the Herald of the Earl, who, although it was so mangled and disfigured as to be scarcely discoverable, recognised him by the loss of his hinder teeth. I find the following account of this in the MSS. of John Anstis, Garter Kingof-Arms, in the Heralds' College. He says-

"But we are assured by a contemporary French historian that his Herald attended on him when he was slain at Chastillon, who had then been his officer-of-arms above forty years, so that he had such in 1st Henry V. The passage is remarkable in discovering to us the customs of that age - that many officers of arms being sent to find out the body of this most valiant Earl, among whom was 'Te Heraud du dit Sieur de Tallebot qui avoit vestu sa cotte d'armes,' and knowing his master by the want of some of his hinder teeth, though his face was so mangled and disfigured with wounds. "Il le baisa en la bouche, en disant ces mots, Monseigneur mon maistre, ce estes vous, je prie a Dieu qu'il vous pardonne vos mesfaits, j'ay este votre officier d'armes quarante ans ou plus, il est temps que je le vous rende, en faisant piteux crys et lamentations, et en rendant eau par les yeux trés pitousment, et alors il revestit sa. cotte d'armes et la mit sur son maistre."

It is worthy of note that the painted portrait effigy of the Earl of Shrewsbury, which used to hang in Old St. Paul's, represented him in his Tabard and in the act of prayer. The original of this picture is in the collection of the Marquis of Northampton at Castle Ashby, and a copy is now in the Record-room of the Herald's College. ${ }^{\prime}$ It is a curious confirmation of the story of the Herald.

But more interesting than this is a photograph, for which I am indebted to the Rev. W. II. Egerton, and from which the engraving is taken, of the skull and jaw found at Whitchurch. In the former the remarkable confirmatory evidence of the axe blow will be observed, and in the latter the no less remarkable testimony of the entire loss of the back teeth. 


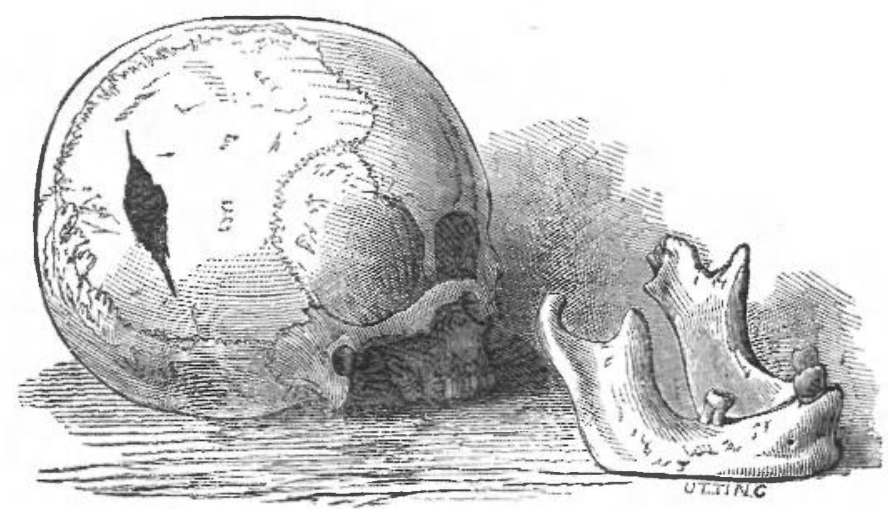

Not the least curious circumstance in connection with the discovery of these bones is, that amongst them was the skeleton of a mouse! "As poor as a church mouse" we have often heard, and this poor mouse had not only sought the shelter of the great Earl's coffin, but the Imperium in imperio of his skull, as a nest to give birth to her young. "It is an ill wind that blows good to no one," and the fatal axe blow had created a convenient entrance for the mouse. Her bones were found mingled with those of the mighty soldier, while those of her young were found within his skull!

Shakespeare, who knew and recorded so much of the Earl, had surely a forecast of this when he wrote-

Hamlet: To what base uses we may return Horatio! Why may not imagination trace the noble dust of Alexander, till he find it stopping a bung-hole!

Horatio: 'Twere to consider too curiously to consider so.

Hamlet: No, faith, not a jot; but to follow him thither with modesty enough, and likelihood to lead it: as thus-Alexander died, Alexander was buried, Alexander returneth to dust; the dust is earth ; of earth we make loam; and why of that loam whereto he was converted, might they not stop a beer.barrel?

Imperious Cresar, dead, and turned to clay,

Might stop a hole to keep the rind away:

$O$, that the earth, which kept the world in awe,

Should patch a wall to expel the winter's flaw!"

For the following, I am indebted to Lord Talbot de Malahide, who copied it from a narrow parchment document in his possession :-- 
En la presence de moy Jehan d'Estampes maistre d'ostel de Monsg ${ }^{\mathrm{r}}$ le Conte d'Angoulesme, Guillaume le Vesville commis par mon dit $\mathrm{S}^{\mathrm{r}}$ a la recepte generale de toutes ses finances a aujourdhui paié et baille par l'ordonnance et commandement de mon dit $\mathrm{S}^{\mathrm{r}}$ les sommes cy apres declarées aux personnes et pour les causes qui ensuivait. C'est a savoir a Reslandire trompette d'icelluy $\mathrm{S}^{\mathrm{r}}$ pour don a luy fait pour les bonnes et joyeuses nouvelles par luy apportées a mon dit $\mathrm{S}^{\mathrm{r}}$ en la ville d'Angoulesme de la mort de Talbot et de la disconfiture des Anglois devant Castillon cinquante cinq sols tournois et a Colinet Goulon pour aler de la dite ville d'Angoulesme a Blois et a Remiremont pour les dites nouvelles a Monsign ${ }^{\mathrm{r}}$ le Duc d'Orleans et a Madame la Contesse d'Angoulesme cinquante cinq sols tournois. Tesmoing mon seign manuel cy mis le xviij jour de Juillet l'an mil ccce cinquante trois.

\section{D'Estampes.}

The following letter appeared in the Standard of the 15th August, 1877, from which it was copied in the Shrewsbury Journal. It was to the Editor of this latter Journal that the reply of the Rector of Whitchurch was addressed :-

Dear Sir,--In a paragraph that appeared in your paper of August 15th, giving a short account of the Royal Archroological Institute's excursion to Goodrich Castle, I find several inaccuracies in connection with the first Earl of Shrewsbury, mentioned in Mr. Stephen Tucker's Paper. The first one is that the great warrior's remains were found at Whitehurch, in Shropshire, in 1864, whereas they were refound in 1874 , at the time the church was undergoing some slight alterations or renovations. The next point I would like to call your attention to is-."At Chatillon (he was then 80 years old) he was unhorsed, and lay for some time on the ground, until, we are told, he was 'des. patched 'by a blow on the head from a battle-axe." When the bones were lying in the vestry of the church at Whitchureh, I had the opportunity of examining them, and on taking up the skull (before I knew that the valiant warrior had been killed by a battle-axe) I remarked that the fracture observable on the left parietal bone had been made with a battle-axe or a sharp weapon having a segmented edge, judging from the shape of the fissure and the marked incision in the bone of the skull at either end of the perforation, I did not measure its length, but [should say that it was about $3 \frac{1}{2}$ inches long, and the piece of bone that had been forced into the brain by the stroke was about two inches in length. The blow had evidently been struck as he was standing unhorsed engaged to a hand to hand fight with an enemy in front, by an enemy coming somewhat behind him and striking him with a battle-axe on the left side of his head, which felled him to the ground, and he, as I imagine, fell 
on his right shoulder and forehead or face, and the blood that flowed from the wound over the left side of the head and face, which was uppermost, disguised him to such an extent as to make his body difficult of recognition, especially if he fell in a muddy or dusty spot. On viewing the skull (a cast of which was taken for the Archreological Society if I am not mistaken) from the clean cut of the gaping fissure and its perpendicular line with the body when in an erect position. shows plainly that it was not received at a time when he was lying unhorsed on the ground, and at the same time, from its position on the skull, there can be no doubt but that he was taken at a disadvantage, and the foeman that dealt it was not facing him at the time fighting hand to hand. Again-" His body was long sought for, and was at last recognised by his herald, by the absence of the hinder teeth, the features having been so injured as to be undistinguishable. The skull found at Whitchurch wants the hinder teeth, and has the hollow caused by the fatal blow." Now the skull at Whitchurch is wrapped round with a kind of narrow linen cloth, about the width now used in bandaging (and as I imagine in those days taken to the field of battle with them to be used for bandaging up of wounds). After the burial of the body at Rouen, come $f \in \mathbb{W}$ years must have elapsed before the skull and bones were wrapped in the cerecloth that now covers them, for every trace of flesh or integument is entirely gone, and it is almost an impossibility to say what teeth he had at the time of his death; from what I could see and judge by the drepressions, risings, or markings on the cerecloth covering the bones of the jaw, he had only one tooth remaining, and that was a dens sapientia or wisdom tooth on the left side of the lower jaw, and I also thought that five or six lower front teeth had fallen out from want of astachment before the bones were covered with the cloth covering that is now on them. It was my intention to have endeavoured to have obtained permission to have taken a cast of the jaw bone, and without the present rovering, so as to lave been able to have given a decided opinion as to the age, \&c., \&c., of the person to whom they had formerly belonged; from what I could see of them I concluded the individual was upwards of 80 years of age, but on my next visit to the torn I learnt that the valiant old Earl was being buried for the third time, and that the late noble Earl was attending his funeral. Again, "Among the bones was found the skeleton of a mouse who had made her nest in the skull of the great Talbot, where the remains of her soung were still remaining. It is an ill wind that blows no one any good. The mouse had entered through the breach made by the battle-axe, but having been unable to escape again from the coffin, had suffered a fate more severe than that which is the proverbial lot of the ordinary church mouse." Now all that reads very prettily, but it will not do, the breach in the skull might admit a silver crown piece, but never a mouse in an interesting condition, who must have gone into the skull to have been confined, for even her progeny never could have squeezed through the fissure; she must have entered through the foramen magnum at the base of the skull before 
it was covered over with cerecloth, and most likely they were in a mummified condition when that was done, otherwise there is no accounting for the circumstance.

Apologising for trespassing so much on your valuable time, I would not have done so had I not considered it my duty if possible to prevent such errors of traditional or hearsay evidence being taken as matter of fact, as every day I am the more convinced of its unreliability. Yours faitlifully, FREDERICK DALBY, Doctor of Dental Surgery.

47, Darlington-street, Wolverhampton, August 16th, 1877.

SrR, - The interesting letter quoted in your columns last week from the Standard invites a few remarks. The purport of that letter was to correct supposed inaccuracies in a lesture on the discovery of Talbot's bones at Whitchurch, delivered by Mr. Stephen Tucker (Rouge Croix) before the Royal Archrological Institute at Hereford. The first inaccuracy is an accidental misprint of 1864 for 1874 . Setting this aside, the writer begins by objecting to the word found as applied to the discovery of the warrior's bones. He says it should have been refound. No such word exists ; but its equivalent in meaning seems to me needless. Talbot's bones were found for the first time in the present church on the 9th of March, 1874. Dr. Dalby's next remarks have reference to the circumstances of Talbot's death. From the vertical character of the cut on the skull, he argues that the body must have been erect when the fatal blow was given. I should have accepted Dr. Dalby's reasoning on this point without hesitation if history had been silent on the subject, but we are confronted by the authority of Hollinshed, who, after having described the siege of the Tower at Chastillon and Talbot's victorious pursuit of the French into their own fortified camp, thus records his death-" Though at firste with manfull courage and sore fighting the Earle wanne the entrie of their camp, yet at length they compassed him about, and shooting him through the thigh with an hand-gunne, slew his horse, and finally killed him, lying on the ground, whom they nover durst look in the face, while he stoode on his feete."-Hollinshed, black letter copy, vol. ii, p. 1285.

The next point in Mr. Tucker's letter, criticised by Dr. Dalby, is that Talbot's body was recognised after the battle "by the absence of the hinder teeth." When the skull was examined there were three incisors and one molar tooth in the lower jaw. There were aparently no teeth in the upper jaw. Certain it is that the body lay for some time on the field of battle until discovered by the Earl's herald, "who broke out into compassionate and dutiful expressions, disrobed himself of his coat of arms, and flung it over his master's body."

We now come to the incident of the mouse's nest in the skull. Mr. Tucker asserts that the entrance to the nest was "through the breach made by the battle-axe." Dr. Dalby says that this " reads very prettily, but that it will not do." In proof of this he states that the gash in the skull was only wide enough to admit a crown piece, and that therefore the mouse must have entered by the foramen magnum. Now the actual dimensions of the gash are 23 
inches in length, and fully $\frac{5}{8}$ of an inch wide in the centre part. Moreover the sides of the orifice bore evidence of ingress and egress, having that peculiar brown semi-polished look which we know so well in the appearance of a mouse-hole. The entrance to the nest was directly beneath the hole, and the cerecloth for some distance round it had been gnawed away by the mice. If the mouse had made her entrance and exit by the foramen magnum she must have done so before the bones were brought from Rouen, for that orifice was closely bound up by the cerecloth. That a French mouse should have increased her progeny in the cavity of Talbot's skull would indeed have been an indignity; but the fact that fragments of the torn leaves of an English prayer book formed part of the substance of the nest, proves to demonstration that the tenant of the skull was none other than an English church mouse. Dr. Dalby is right in condemning the substitution of traditional or hearsay evidence for matter of fact. I have endeavoured to supply him with some facts which reduce his list of inaccuracies to a minimum, and substantiate in every important particular the correctness of the statements made by Rouge Croix.

I am, \&c.,

W. H. EGERTON.

As an actual instance of the base uses to which even kings return, it may be mentioned that when the tomb of King John was opened in 1797 "a vast quantity of the dry skins of maggots" were found within the royal coffin. Some of these were purloined by an ingenious sentleman of Worcester, who, baiting his hook with them, and toiling for three days, finally drew it dace out of the Severn, which he bore in triumph through the streets. A workman stole a fingerbone, and sent it to London to be tipped with silver, but it was lost on the road. -See GodgH's Sepulchral Monuments, vol. ii, part i, p. 331, and Greese's Account of the Opcring.-ED. 